\title{
The Effect of Concept Sentence Learning Model in Improving Learning Achievement of Social Sciences for Student with Hearing Impairment
}

\author{
Munawir Yusuf \\ Universitas Sebelas Maret \\ Surakarta Indonesia \\ munawir_uns@yahoo.co.id \\ Istiqomah Putri Mirasandi \\ Universitas Sebelas Maret \\ Surakarta Indonesia \\ munawir_uns@yahoo.co.id
}

\author{
Erma Kumala Sari \\ Universitas Sebelas Maret \\ Surakarta Indonesia
}

\begin{abstract}
The research was conducted to determine the effect of the concept sentence learning model in improving the learning achievement of social sciences for a student with hearing impairment class VII in SLB B YRTRW Surakarta. The research used the experimental method with one group pre-test and post-test design consisted of pretest, treatment, and posttest. The treatment was done 4 times $(90$ minutes for each meeting). The subjects of the research were eight students with hearing impairment of class VII in SLB B YRTRW Surakarta. The sampling technique used in this research was non-probability sampling with purposive sampling. The data collection was carried out by written test consisted of 27 questions. Content validity was used to test the validity of the test instrument, while Alpha-Cronbach formula was used to test the reliability. The validity test showed that the test instrument was valid, while the reliability test also showed that the test instrument was reliable $(r=0.997)$. Data analysis technique used in this research was the non-parametric analysis with Wilcoxon Signed Rank test. The result showed that the mean score of posttest (76.11) was higher than the mean score of pretest (48.6). Based on the nonparametric analysis statistic value with Wilcoxon Signed Rank test $\left(Z Z_{\text {score }}=-2.524\right.$; Asymp.Sig=0.012 $\left.(<0.05)\right)$, it can be concluded that the concept sentence learning model affects the learning achievement of social studies for a student with hearing impairment class VII in SLB B YRTRW Surakarta.
\end{abstract}

Keywords - Effect, Concept Sentence, Learning Achievement, Social Sciences, Hearing Impairment

\section{INTRODUCTION}

Hearing impairment is a general term of hearing difficulties, which classified into deaf and hard of hearing, which has impacts to vocabulary, speaking, and communication difficulties [1], [2]. The limitation of vocabularies of children with hearing impairment cause some troubles in the academic field.

The vocabulary, abstract words, and way of talking affects the understanding of sentence or passage in children with hearing impairment [3], [4]. Different with children in general, children with hearing impairment did not learn about prepositional phrase since an early age. This condition causes the failure of children with hearing impairment in understanding the concepts of a lesson. Moreover, there is almost no preposition in sign language. Thus, there are significant differences in grammar between normal children and children with hearing impairment [5].

Children with hearing impairment communicate not only using sign language but also using written language. Children with hearing impairment from hearing families have a better ability to read and write, but the use of sign language shows the better results in supporting learning process of children with hearing impairment in school [6].

The learning process of children with hearing impairment has no different from normal children. Therefore, there are a few modifications of the learning process to suit the needs of children with hearing impairment. Children with hearing impairment usually have difficulty in following the learning especially on the subjects which consist of verbal materials, such as social science. In social science, the teacher usually uses expository learning model by lecturing method in presenting the material. Thus, children with hearing impairment will be difficult to follow the teacher's explanation. It will have an impact on the learning achievement of children with hearing impairment.

A learning achievement is the result of student's effort during the learning activities as a result of changes in behavior that includes cognitive, affective and psychomotor which is a measure of student's success in learning activities [7], [8]. A high learning achievement is one of the indicators of the success of the learning process. Therefore, not all of the students in school can reach high learning achievements. There are some students who get low learning achievements. It can be caused by the lack of students' ability to understand the materials. However, the low ability of students can be optimized by applying appropriate and effective learning model. Thus, the teacher should be able to choose appropriate 
learning models for their students, especially students with hearing impairment.

A Concept Sentence is a learning model which began of the delivery of competency, presentation of material, heterogeneous group making, presentation of appropriate keywords of teaching materials, and group assignments. Moreover, it will be continued by presenting the students' study results to the class alternately. This model is done by forming a heterogeneous group of students and making a sentence with 4 keywords in minimum according to materials presented [9] \& [10]. Children with hearing impairment have less ability in all language domains than hearing children which impact on their oral language [11]. The sentence concept learning model can be applied to students with hearing impairment because it does not require students to talk but work more by using thinking skills to make a sentence from the keywords that have been provided.

Thus, the purpose of the study was to determine the effect of concept sentence learning model in improving learning achievement of social science for students with hearing impairment class VII in SLB B YRTRW Surakarta.

\section{METHODS}

The research was a quasi-experimental with one group pretest-posttest design. The experiment consisted of pretest, treatment, and posttest to test the influence of the treatment given [12]. The independence variable of this study was concept sentence learning model, while the dependence variable was learning achievement of social science. The treatment (concept sentence learning model) was given four times (90 minutes for each meeting) to improve the learning achievement of social science.

This study was conducted in SLB B YRTRW Surakarta in 2017. There are 8 students with hearing impairment of class VII participated as the subject of this study. The sampling technique of this research was non-probability sampling with purposive sampling. Data was collected by a test consisted of 27 questions. Content validity was used to test the validity of the test. Content validity is a validity testing carried out to determine whether the items of an instrument have measured precisely the circumstances wanted to be measured [13]. Meanwhile, Cronbach Alpha formula was used to test the reliability of the test instrument. The result of validity test showed that the test instrument was valid, while the result of reliability test showed that the test instrument was reliable $(r=0.997)$. Data analysis techniques used in this study was a non-parametric statistical analysis of Wilcoxon signed rank test.

\section{RESULTS AND DISCUSSION}

\section{A. Descriptive Statistic}

Based on table 1, the mean score of posttest (76.1) was higher than the mean score of pretest (48.6). All of the subjects in this research get a higher score in posttest than in pretest. Thus, the descriptive statistic result showed that the learning achievement of social science of students with hearing impairment class VII in SLB B YRTRW Surakarta increase from 48.6 in pretest to 76.1 in the posttest.

TABLE I. DESCRIPTIVE STATISTIC

\begin{tabular}{|l|c|c|c|c|c|}
\hline & N & Minimum & Maximum & Mean & SD \\
\hline Pretest & 8 & 44 & 56 & 48,61 & 3,433 \\
\hline Posttest & 8 & 67 & 89 & 76,11 & 7,102 \\
\hline $\begin{array}{l}\text { Valid N } \\
\text { (listwise) }\end{array}$ & 8 & & & & \\
\hline
\end{tabular}

\section{B. Statistical Test (Wilcoxon Sign Rank Test)}

Table 2 and 3 showed the statistical tests calculated with SPSS 22 which acquired Z count of -2.524 with Asymp.Sig (2tailed) of $0.012(<0.05)$. Thus, the hypothesis of this research was accepted. It can be concluded that the concept sentence learning model affects learning achievement of social science for students with hearing impairment class VII in SLB B YRTRW Surakarta.

TABLE II. DATA ANALYSIS OF WILCOXON SIGN RANK TEST

\begin{tabular}{|c|c|c|c|c|}
\hline & & $\mathbf{N}$ & Mean Rank & $\begin{array}{c}\text { Sum of } \\
\text { Ranks }\end{array}$ \\
\hline \multirow{4}{*}{$\begin{array}{c}\text { Posttest- } \\
\text { Pretest }\end{array}$} & Negative ranks & $0^{\mathrm{a}}$ & , 00 &, 00 \\
\hline & Positive ranks & $8^{\mathrm{b}}$ & 4,50 & 36,00 \\
\hline & Ties & $0^{\mathrm{c}}$ & & \\
\hline & Total & 8 & & \\
\hline
\end{tabular}

a. Posttest $<$ Pretest

b. Posttest $>$ Pretest

c. Posttest $=$ Pretest

TABLE III. THE RESULTS OF STATISTICAL TEST (WILCOXON SIGN RANK TEST)

\begin{tabular}{|c|c|}
\hline & Posttest - Pretest \\
\hline $\mathrm{Z}$ & $-2,524^{\mathrm{b}}$ \\
\hline Asymp.Sig (2-tailed) &, 012 \\
\hline
\end{tabular}

a. Wilcoxon signed ranks test

b. Based on negative ranks

\section{Discussion}

Based on the results above, it can be concluded that the concept sentence learning model can influence in improving social science learning achievement of students with hearing impairment. The result of this research is also supported by the results of the previous studies. The previous studies also showed that there was an increase in social science learning achievement of students after being given a sentence concept learning model [14], [15].

The result shows that concept sentence learning model is one of learning model which is appropriate to be applied to students with hearing impairment to improve the low learning achievement, especially a learning achievement of social science. The concept sentence learning model can improve the social science learning achievement of students with hearing impairment because of it requires students to solve problems by making sentences from the keywords that have been provided so it can encourage students to think critically [16]. In addition, students also more easily understand the material by presenting the keywords in each material. 
The selection of keywords and the order of the keywords provided affect the perception or the concept in understanding a sentence. Ref. [17] explained that some words that represent the concept of the sentence will affect a person's perception in understanding the sentence. The change of the word will lead to different perceptions. Meanwhile, the order of the keywords affects the perception of the sentence [18].

A material can be easily understood by giving the keywords on the main material. Giving the keywords in the material will help students in understanding the concept of the material as it is presented in the form of basic concepts in brief, precise, and concise. Ref. [19] also stated that concept sentence learning model is a model of instructional which teach students to make a sentence with some keywords that have been provided so that students can understand the concept contained in a sentence. An understanding of a concept can improve students' learning achievement as students analyze the relationship between the words that form a concept. It makes the students understand the material which impacts to the improvement of students' learning achievement [20].

The understanding of materials makes the material becomes easier to remember. The ability to remember closely relates to the learning achievement. In educational psychology, memory can support the learning process. In the learning process, students need a strong memory to absorb and understand the learning material. A higher ability of memory will result in a higher academic achievement in the learning process.

The implementation of concept sentence learning model requires students to be more creative. Students should think to choose the appropriate words to connect the keywords that have been provided in order to arrange them to become an appropriate sentence. Ref. [21] argued that this model provides greater opportunities for students to get ideas and creativities based on the keywords that have been assigned by the teacher.

Based on the observation of the treatment process, the implementation of concept sentence model also improves the participation of the students in the process of learning. They become more active in giving an opinion to the group in discussing the answer of the assignments given and discussing of the appropriate sentence. In addition, students become more interested in following the learning process which conducted by concept sentence learning model. It also can be seen from the observation result of the treatment process. Students become more focus and give more attention during the learning process. They assume that the materials given will be very boring when they are explained by teacher lecturing. Learning process by a discussion with other group members makes the students can participate actively in the learning process. Discussions in a learning activity also increase student interaction with group members that have an impact on student learning achievement. The discussion process in concept sentence model brings new innovation, though the discussion in learning process has often conducted in schools in general.

The learning atmosphere also becomes more interesting by doing a discussion with friends to construct a sentence according to the keywords given. This situation motivates the students to learn more actively so that the students' learning achievement can increase. The role of motivation in the learning process is very important. Ref. [22] explained that one of the roles of motivation is to provide the passion, enthusiasm, and joy in learning for students to carry out the learning activities.

Based on the observation results of the treatment, there are several advantages of concept sentence learning model. First, the provision of keywords in the subject matter facilitates the understanding of the material. Next, the learning materials can be easier to remember. Moreover, students become more creative in choosing words that correspond to the appropriate sentence. Besides, students become more active in delivering opinions during discussions with members of the group. In addition, students become more interested in following the learning. The discussion process in concept sentence learning model increases the interaction of the group members. Last, the concept sentence learning model motivates the students to study because of the pleasant atmosphere in learning.

Therefore, it can be concluded that the use of concept sentence learning model affects learning achievement of social studies for students with hearing impairment class VII in SLB B YRTRW Surakarta.

\section{CONCLUSION}

Based on the results, it can be concluded that the concept sentence learning model affects learning achievement of social science for students with hearing impairment class VII in SLB B YRTRW Surakarta. Therefore, it is expected that teachers can apply the concept sentence learning model to improve social science learning achievement of students with hearing impairment.

\section{REFERENCES}

[1] Winarsih. M. Intervensi Dini bagi Anak Tunarungu dalam Pemerolehan Bahasa. Jakarta: Departemen Pendidikan dan Kebudayaan, 2007.

[2] Efendi, M. Pengantar Psikopedagogik Anak Berkelainan. Jakarta: Bumi Aksara, 2009.

[3] Kyle, F.E., Ruth, C., \& Mairead, M. The Relative Contributions of Speechreading and Vocabulary to Deaf and Hearing Children's Reading Ability. Research in Developmental Disabilities, 48, 13-24, 2016.

[4] Giang, D.L., \& Chung, I. Comprehensive of Figurative Language by Hearing Impaired Children in Special Primary Scholls. Procedia - Social and Behavioral Sciences, 191 (2015), 506-511, 2015.

[5] Vitova, J., \& Balcarova, J. Language Competence Versus The Mathematical Concepts of Pre-school Children with Hearing Impairments. Procedia - Social and Behavioral Sciences, 69, 2076-2081, 2012.

[6] Zaitseva, I., \& Brokane, L. Acquisition of the Sign Language and Spoken/ Written Language for Hearing-Impaired Children at Pre-School Educational Establishments in Lativa. Procedia - Social and Behavioral Sciences, 60, 124-135, 2012.

[7] Suryabrata, S. Psikologi Pendidikan. Jakarta: Raja Garfindo Persada, 2006.

[8] Winkel, W.S. Psikologi Pengajaran. Yogyakarta: Media Abadi, 2007.

[9] Ngalimun. Strategi dan Model Pembelajaran. Yogyakarta: Asmaja Pressindo, 2016.

[10] Suprijono, A. Cooperative Learning: Teori dan Aplikasi Paikem. Yogyakarta: Pustaka Pelajar, 2012.

[11] Liu, X., et al. New Language Outcome Measures for Mandarin Speaking Children with Hearing Loss. Journal of Otology, 11, 24-32, 2016. 
[12] Sanjaya, W. Penelitian Pendidikan : Jenis, Metode, dan Prosedur. Jakarta: Kencana, 2014.

[13] Purwanto. Evaluasi Hasil Belajar. Yogyakarta: Pustaka Pelajar, 2013.

[14] Wihelma, F. Penerapan Model Concept Sentence untuk Meningkatkan Proses dan Hasil Belajar Siswa Kelas IV Mata Pelajaran IPS di SDN Lesonpuro III Kecamatan Kedungkandang Kota Malang, 2011.

[15] Khoirullah, E. M., Yarmaidi., \& Rahma, K.S.U. Perbedaan Hasil Belajar Siswa dengan Menggunakan Pembelajaran Concept Sentence dan Konvensional, 2016.

[16] Huang, M.Y., et al. Effects of cooperative learning and concept mapping intervention on critical thinking and basketball skills in elementary school. (Electronic version). Thinking Skills and Creativity, 23, 207216, 2017.

[17] Guediche, S., Reilly, M., Santiago, C., Laurent, P., dan Blumstein, S.E. An fMRI Study Investigating Effects of Conceptually Related Sentences on the Perception of Degraded Speech (Electronic version). Cortex, 79, 57-74, 2016.

[18] Tanaka, M.N., Branigan, H.P., McLean, J.F., dan Pickering, M.J. Conceptual Influences on Word Order and Voice in Sentence Production: Evidence from Japanese (Versi Elektronik). Journal of Memory and Language. 65, 318-330, 2011.

[19] Huda, M. Model-model Pengajaran dan Pembelajaran Isu-isu Metodis dan Paradigmatis. Yogyakarta: Pustaka Pelajar, 2013.

[20] Marquez, J.G., \& Carlos, P. Concept Maps and Simulations in a Computer System for Learning Psychology. European Journal of education and Psychology, 10, 33-39, 2016.

[21] Kiranawati. Model Pembelajaran Inovatif. Jakarta: Media Persada, 2008.

[22] Siregar, E. \& Nara, H. Teori Belajar dan Pembelajaran. Bogor: Ghalia Indonesia, 2011. 